\title{
ENGINEERING FACTOR AFFECTING ORGANIC COMPOST PRODUCTION
}

\author{
Zaalouk, A. K. K.(1); Mosallam, M. A. ${ }^{(1)}$; EL-Soaly, I. S. A. ${ }^{(1)}$; \\ Mohamed, A. L. ${ }^{(2)}$ and Khfagy, O. N. ${ }^{(3)}$
}

\section{ABSTRACT}

This study make it in abo grida factory of recycling waste damietta, aims to evaluting the effect of three levels of ventilation: 0.7, 1.2 and $1.7 \mathrm{~L} / \mathrm{m}$ and two levels of agitation: 25 and $50 \mathrm{rpm}$ on the fermentation of an oraganic waste. An agitated and aerated composter and wetting compster was constructed to achive this goal. The study ended to that 0.7 $L / m$ vintillation rate and $25 \mathrm{rpm}$ agitating rate is the best compered to the other tested levels.

\section{INTRODUCTION}

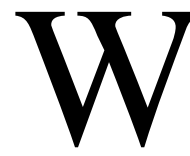

aste is the outcome of human activity which is produced since humans started living. Urban waste causes pollution environmental and represent great problem in its storage. Treating wastes by aerobic fermentation transform the waste into an organic fertilizer and this fertilizer increases the benefits of the agriculture's product. It is notable that the organic agriculture produces is high in its price and this is due to it high quality. This research aims to study effect of chosen ventilation rates and chosen agitation rates on the production of compost. Hong et al. (1983) studied the high rapid composting of dairy cattle manure with crop and forest residues. They found that the control of the optimal aeration $\mathrm{PH}$ value, bulk weight and moisture content in batch type composter should be necessary for composting. Hong et al (1983) found that composting may be anaerobic or aerobic. The anaerobic process is very slow, takes places at a low temperature and produce foul odors. The anaerobic process required 6 months for completion to occur. The process was aerobic later modified by turning the pile over twice, which reduced the composting time to 3 months. Dariy manure can be composting in a batch composter in about 7 days. They found that the required time for composting based on a few days in the high temperature of 40 to $70^{\circ} \mathrm{C}$, amount to 4 to 7 days under the suitable conditions.

\footnotetext{
(1) Prof. of Ag. Eng., Fac. of Ag. Eng, Al-Azhar Univ., Cairo.

(3) Prof.; Ag. Eng. Res. Ins., Ag. Res. Center, Dokki, Giza.

(4) MSc. Stu. of Ag. Eng., Fac. of Ag. Eng., Al-Azhar Univ.
} 
Hong et al (1983) found that the temperature of the compost rose rapidly within 12 hours after the mixture was placed in the composter and reached a peak 27.5 to $75^{\circ} \mathrm{C}$ within 18 hours to 7 days on the aeration rate from 0.04 to $3,00 \mathrm{~L} / \mathrm{min} . \mathrm{kg}$ per volatile matter. Compost sometimes attain temperature as high as $80 \mathrm{C}^{\circ}$ which stops the growth of the thermo actionomyces until the temperature drops to $65^{\circ} \mathrm{C}$ or below. The optimal temperature based on the oxidation of organic matter in to carbon dioxide and water is $60^{\circ} \mathrm{C}$. The thermophilic range 55 to $70^{\circ} \mathrm{C}$ has been found to be the most efficient range for composting. The recorded temperature showed excessive aeration had a pronounced cooling effect. At very low aeration rate for the oxygen supply was limited and also decomposition was anaerobic change. The aerobic process was relatively rapid. High temperatures were produced by the aerobic oxidation of organic matter. The suitable temperature based on oxidation for organic matter into carbon dioxide and water was between 40 and $70^{\circ} \mathrm{C}$. A high temperature of 55 to $70^{\circ} \mathrm{C}$ was generally affected by the aeration rate, bulk weight, $\mathrm{pH}$ value, distribution of fine and coarse particle size and moisture content. A decrease in the composting rate was observed at 70 to $75^{\circ} \mathrm{C}$ the maximum composting rate was obtained in the range of 65 to $70^{\circ} \mathrm{C}$.

Ahmed et al. (2013) pointed out that in composting the main factor that can be most influenced by the technology, around which system design are developed, and is the availability of oxygen .With respect to design, the equipment for providing aeration range from the relatively simple to the very complex. This range leads to generalized classification of compost technology described earlier as open (windrow, pile) and closed (mechanical, in a vessel or container).

\section{MATERIAL AND METHODS}

\section{Collecting waste}

wagons lifted bags of waste from different places to recycling plant, fig(1), these waste inclined belts by loaders Waste passes through horizontal belts worker open cases of waste and separate organic matter from waste the waste passes on around riddle to $10 \mathrm{~cm}$ holes to separate stones are bigger than $10 \mathrm{~cm}$ and organic waste is collected after that.

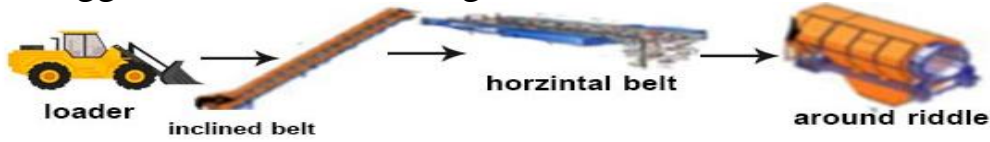

Fig. (1) System of collecting and separating waste. 


\section{The used composter:}

A composter was designed and constructed and installed inside laboratory of home waste recycling factory ,abo grida Damitta to study and evaluate its performance in rapid composting of home waste. the reattach was carried out from December 2016 to March 2017. The composter is cylindrical in shape, and made from metal sheet of $2 \mathrm{~mm}$ thickness. The gross dimension of composter are $28 \mathrm{~cm}$ diameter and its $54 \mathrm{~cm}$ high, its net volume is $0.03 \mathrm{~m} 3$ as shown in figs (2) and (3). the upper of the composter is capped using a movable stainless steel lid to darken the composter.

To supply an adequate amount of air for providing and maintaining the presence of oxygen in the composted matereide, air usually supplied to the composted matereide through air plenum chamber with $10 \mathrm{~cm}$ hight by acomposter as shown in fig (3).three levels of aeration were used .these levels are:0.7,1.2, and $1.7 \mathrm{~L} / \mathrm{min}$.

To provide and maintain the porosity necessary for composting, the mixture of home waste was mechanically agitated using a vertical agitator placed on the center line for composter.

A perforated metal sheet was installed above the bottom of the composter located $10 \mathrm{~cm}$ from the bottom to aid the aeration of the composted material the composter was connected to a compressor with volume of 200 liters, the compost was aerated for $24 \mathrm{~h}$ per day .

Agitator consists of three blades, each blade $17 \mathrm{~cm}$ long, $1.5 \mathrm{~cm}$ wide and $4 \mathrm{~mm}$ thick. The agitator taken its motion from an electrical motor 0.75 hp with gearbox to reduce its speed to about 25 and $50 \mathrm{rpm}$. The water enters in to upper of composter by small pump. The motor power is transmitted through two pulleys through a belt.

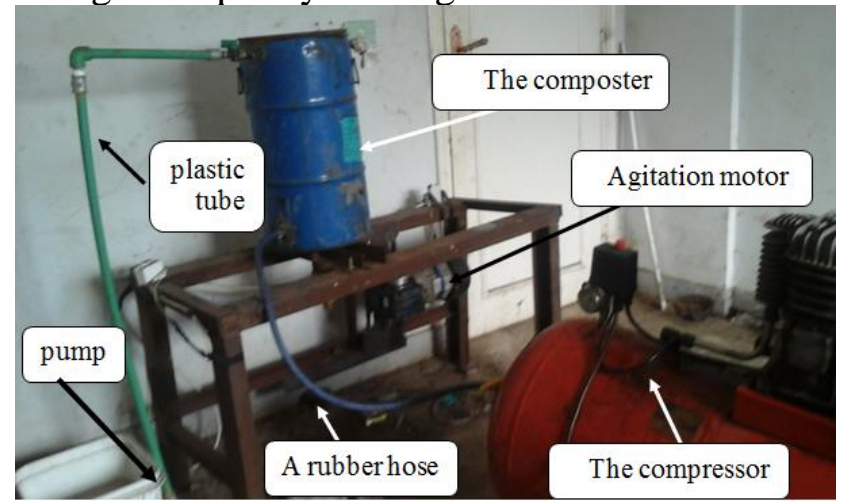

Figure (2) the composter 


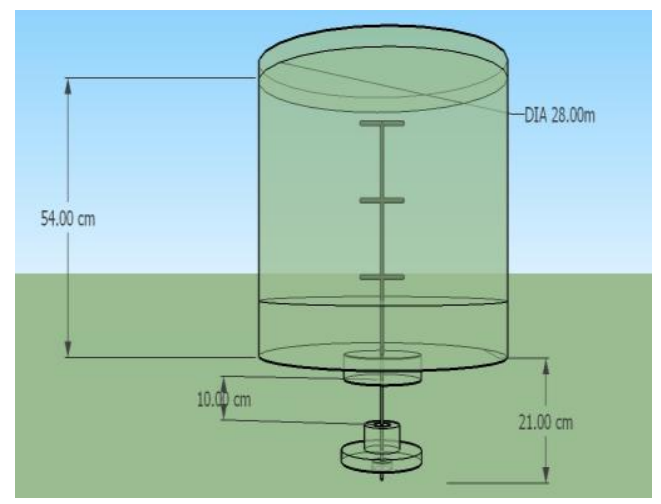

Fig. ( 3 ) isoun the constructed system for process in waste compost dimension of using composter, drawn to scale, dim in $\mathrm{cm}$

\section{Experiments}

At the beginning of each experiment, moisture of compost was altered to $55 \%$ dry basis.

Experiments were carried out under three level of aeration which are 0.7, 1.2 and 1.7and two levels of agitation which are 25 and $50 \mathrm{rpm}$

Studied factors which affect composting:

1. Temperature difference between inside and outside of composter.

2. PH of composting.

3. Density of composting at beginning and end of composting.

\section{Moisture content of the waste.}

\section{RESULTS AND DISCUSSION}

The mean of waste moisture was determined. measuring moisture of waste was started on 22/12/2014 and the experiments of this research was started on $12 / 2016$ and lasted till $3 / 2017$. Hence the period of the experiments matches period of estimating moisture of the waste. Fig.1 shows the relation between moisture of the waste on a wet basics and time in day.

\section{Temperature Difference mean $\left(\mathrm{C}^{\circ}\right)$}

The given two groups of carves fig $(1 \mathrm{~A}-1 \mathrm{C})$ and $(2 \mathrm{~A}-2 \mathrm{C})$ represents the relation between time of composting and composter temperature and ambient temperature under tested ventilate rates $(0.7-1.2-1.7) 1 /$ mine. For the whole treatments, the first group is under agitation rate (25) rpm and the second under (50) rpm. 


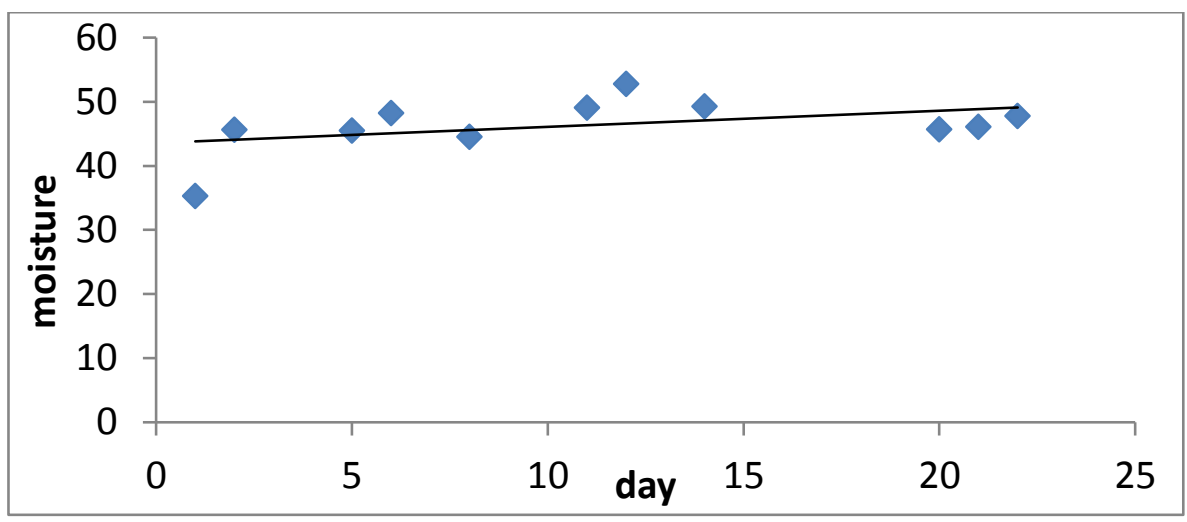

Fig.1 moisture of waste through out one month

From the table (1) which corresponds to the Wright 3 figures show average of each of composter temperature and ambient temperature which were calculated. The average for composter of figs (1A-1C) is in order: $24.5,21.5$ and $19.5 \mathrm{C}^{\circ}$.corresponding ambient temperature were $22,20.5$ and $17.3 \mathrm{C}^{\circ}$. For each ventilation rate treatment, the difference between composter temperature and the ambient temperature were calculated and recorded in tables 1 and 2

Table (1) temperature difference and average compost and ambient temperature under $25 \mathrm{rpm}$

\begin{tabular}{|c|c|c|c|}
\hline $\begin{array}{c}\text { ventilation } \\
\text { rats }(1 / \mathrm{min})\end{array}$ & $\begin{array}{c}\text { temperature } \\
\text { Different }\end{array}$ & $\begin{array}{c}\text { Average ambient } \\
\text { temperature }\end{array}$ & $\begin{array}{c}\text { Average composter } \\
\text { temperature }\end{array}$ \\
\hline 0.7 & 2.5 & 22 & 24.5 \\
\hline 1.2 & 1 & 20.5 & 24.4 \\
\hline 1.7 & 2 & 17.3 & 19.2 \\
\hline
\end{tabular}

Table (2) temperature difference and average compost and ambient temperature unable $50 \mathrm{rpm}$

\begin{tabular}{|c|c|c|c|}
\hline $\begin{array}{c}\text { ventilation } \\
\text { rats(1/min) }\end{array}$ & $\begin{array}{c}\text { Different } \\
\text { temperature }\end{array}$ & Ambient & composter \\
\hline 0.7 & 1 & 15.3 & 16.6 \\
\hline 1.2 & 0.9 & 16.6 & 17.5 \\
\hline 1.7 & 0.6 & 17.6 & 18.2 \\
\hline
\end{tabular}

As the difference between composter temperature and ambient temperature increased this is an indicator of a better composting digestion.

From tables 1 and 2 : the ventilation rate that gives greater difference in temperature $\left(2.5 \mathrm{C}^{\circ}\right)$ is $0.7 \mathrm{~L} / \mathrm{Min}$ (lowest tested ventilation air) and $25 \mathrm{rmp}$ 
for agitation .(lowest rpm agitation) gave a reasonable treatment for saving energy (ventilation and mixing ) so 0.7 rate of ventilation and air $25 \mathrm{rpm}$ agitation seems to be suitable for managing a composter.

Fig. (1A)

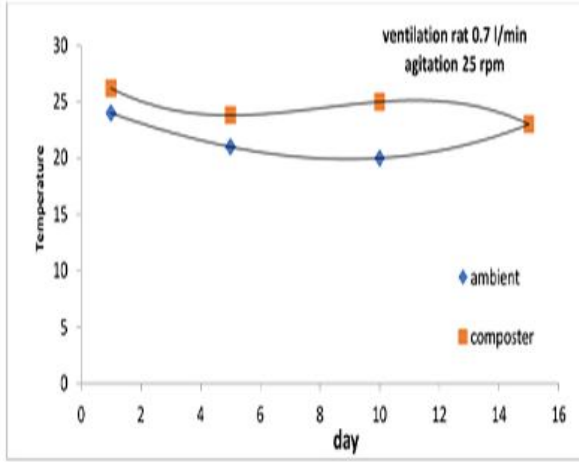

Fig. (1B)

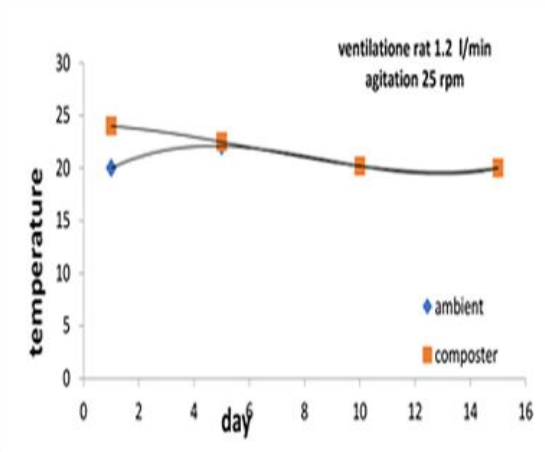

Fig. (1C)

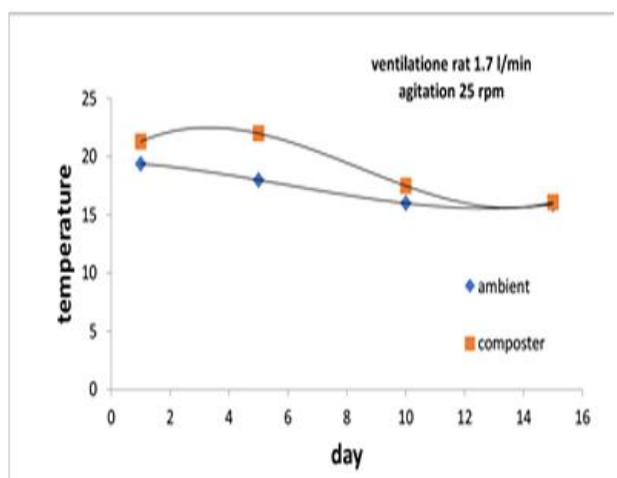

Fig. (2A)

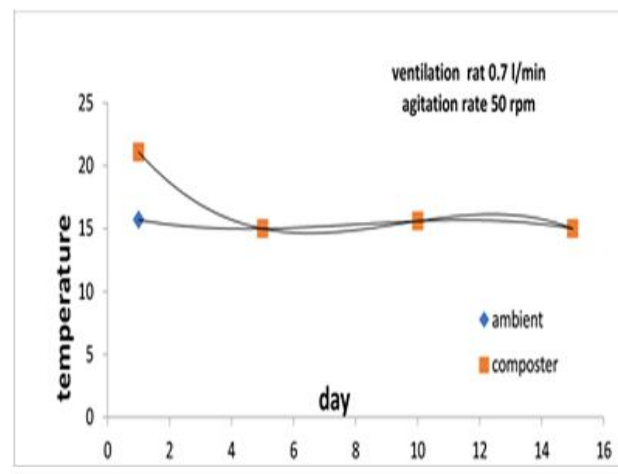

Fig. (2B)

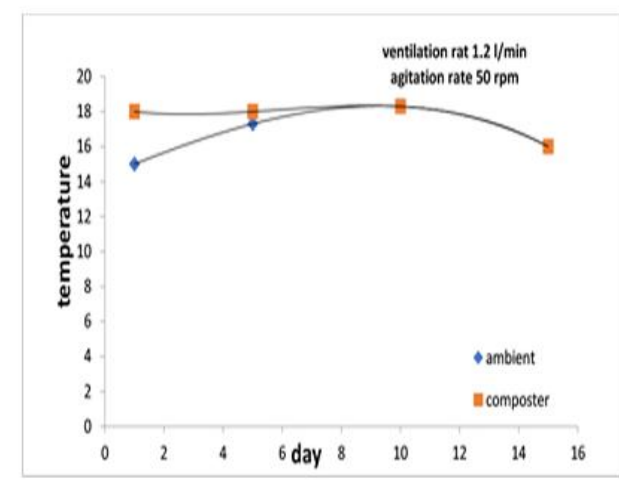

Fig. (2C)

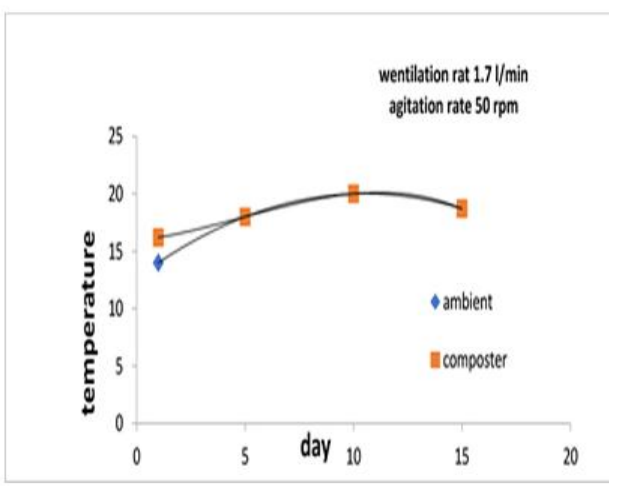

Figs. 1A through $2 \mathrm{C}$ the relationship between time (day) and temperature (composter and ambient) 
The following two groups of carves fig $(3 \mathrm{~A}-3 \mathrm{C})$ and $(4 \mathrm{~A}-4 \mathrm{C})$ represents the relation between time of composting and $\mathrm{PH}$ for each treatment under tested ventilate rates $(0.7-1.2-1.7) 1 /$ mine and whole treatment moisture was constant $(55 \%)$. The first group is under rpm agitation (25) and the second under (50).

Fig. (3A)

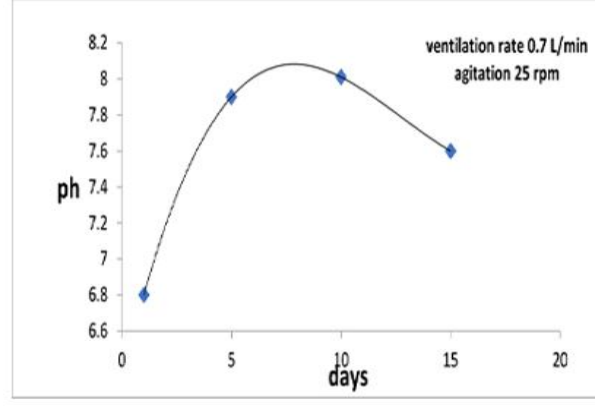

Fig. (3B)

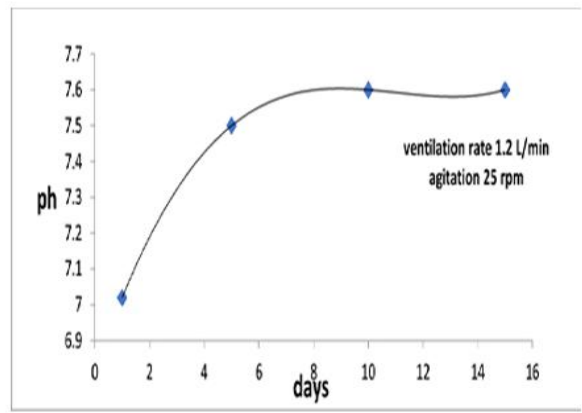

Fig. (3C)

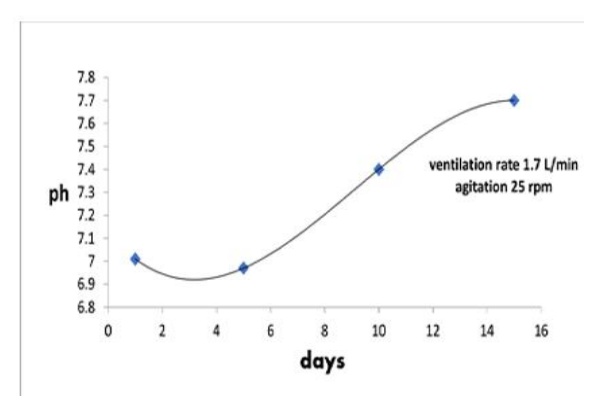

Fig.(4A)

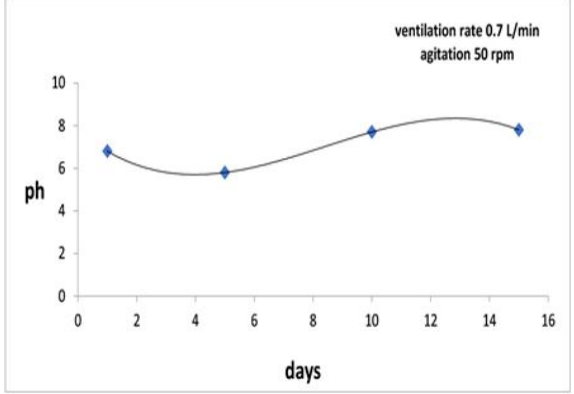

Fig. (4B)

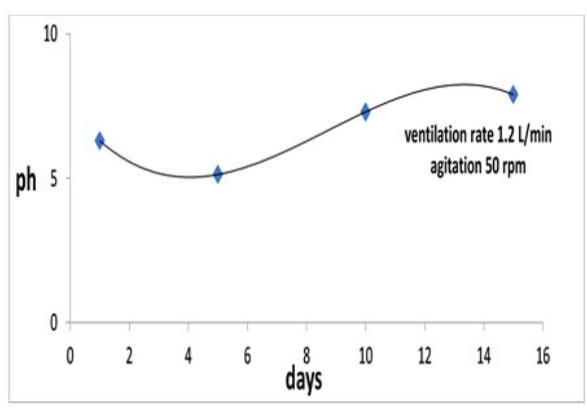

Fig. (4C)

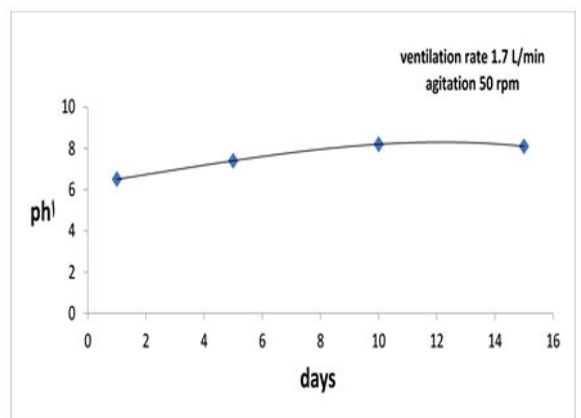

Figs. 3A through $4 \mathrm{C}$ the relationship between time (day) and $\mathrm{pH}$

Figs $3 \mathrm{~A}$ through $4 \mathrm{C}$ shows that, generally, the $\mathrm{pH}$ value increase with time. The last measured $\mathrm{PH}$ (at the end of 15 days of for each treatment) is in its least value, $\mathrm{pH} 7.6$, for the two treatments $0.7 \mathrm{~L} / \mathrm{min}, 25 \mathrm{rpm}$ and 
1.2 $\mathrm{L} / \mathrm{min}$ and $25 \mathrm{rpm}$. For the rest of treatments, $\mathrm{pH}$ value increase the previously mentioned value (7.6) so treatment of $0.7 \mathrm{~L} / \mathrm{min}$ ventilation rate and $25 \mathrm{rpm}$ agitation rate in preferred from point of view of $\mathrm{PH}$.

Density on dry basis:

For all treatments, the fitting line of values of density dry basis increases as time of composting increases. Table (3) shows the value of density on dry basis at the end of each treatment, from the table greatest value of density is under $0.7 \mathrm{~L} / \mathrm{min}$ ventilation and $25 \mathrm{rpm}$ agitation ratio.

\begin{tabular}{|l|l|}
\hline Treatment & $\begin{array}{l}\text { Density of dry basis at the } \\
\text { end of experiment }\end{array}$ \\
\hline Ventilation rate $0.7 \mathrm{~L} / \mathrm{min}$ agitation rate $25 \mathrm{rpm}$ & 0.29 \\
\hline Ventilation rate $1.2 \mathrm{~L} / \mathrm{min}$ agitation rate $25 \mathrm{rpm}$ & 0.23 \\
\hline Ventilation rate $1.7 \mathrm{~L} / \mathrm{min}$ agitation rate $25 \mathrm{rpm}$ & 0.20 \\
\hline Ventilation rate $0.7 \mathrm{~L} / \mathrm{min}$ agitation rate $50 \mathrm{rpm}$ & 0.24 \\
\hline Ventilation rate $1.2 \mathrm{~L} / \mathrm{min}$ agitation rate $50 \mathrm{rpm}$ & 0.26 \\
\hline Ventilation rate $1.7 \mathrm{~L} / \mathrm{min}$ agitation rate $50 \mathrm{rpm}$ & 0.18 \\
\hline
\end{tabular}

Fig 5A through $6 \mathrm{C}$ shows the relation between time and density of compost under the six treatments.

Fig. 5A

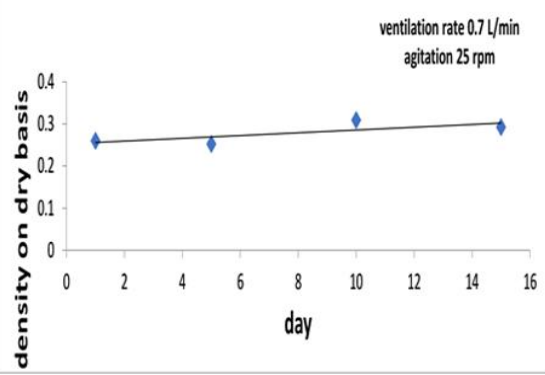

Fig. 5A

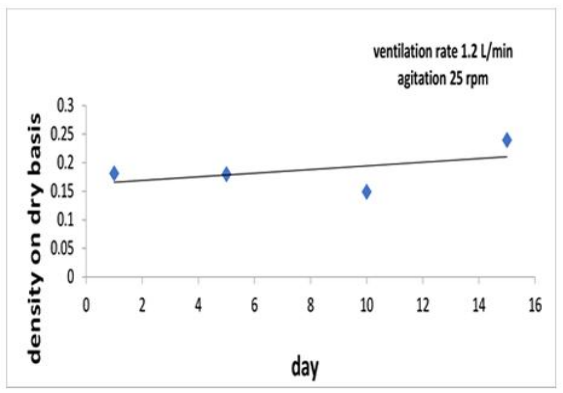

Fig. 6A

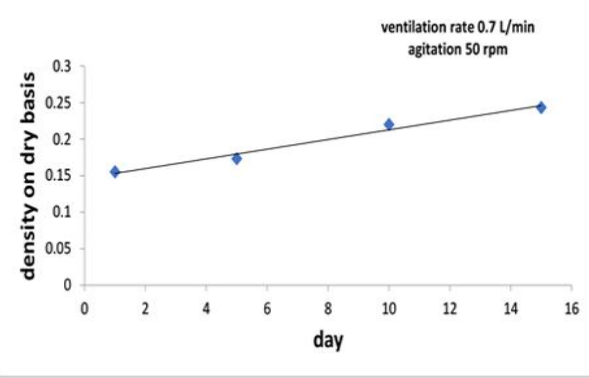

Fig. 6B

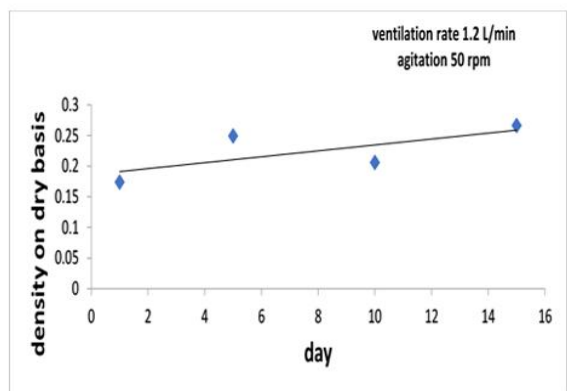


Fig. 5C

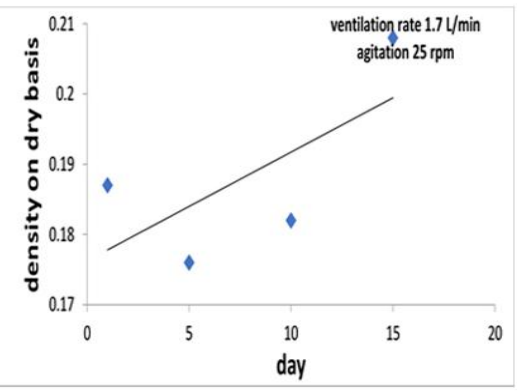

Fig 6C

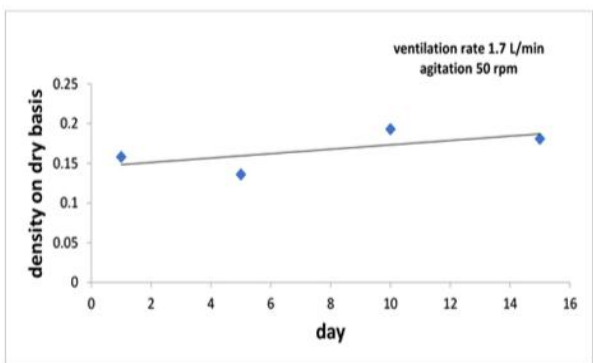

Figs. 5A through $6 \mathrm{C}$ the relationship between time (day) and density of compost

CONCLUSION

Table 4 summery the result of the whole experiments of the research

\begin{tabular}{|c|c|c|c|c|c|c|c|c|}
\hline \multicolumn{2}{|r|}{ Treatment } & \multirow{2}{*}{$\begin{array}{l}\text { Temperatur } \\
\text { e Difference } \\
\text { mean }\left(C^{\circ}\right)\end{array}$} & \multicolumn{2}{|c|}{ PH } & \multicolumn{2}{|c|}{$\begin{array}{l}\text { Density on wet basis } \\
\mathrm{g} / \mathrm{cm}^{3}\end{array}$} & \multirow{2}{*}{$\begin{array}{c}\text { Mixing } \\
\text { power } \\
\mathrm{kW}\end{array}$} & \multirow{2}{*}{$\begin{array}{l}\text { Density on dry } \\
\text { basis at the end or } \\
\text { experiment } \mathrm{g} / \mathrm{cm}^{3}\end{array}$} \\
\hline 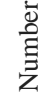 & Describe & & Beginning & end & Beginning & end & & \\
\hline 1 & $0.7 \mathrm{l} / \mathrm{min} 25 \mathrm{RPM}$ & 2.5 & 6.8 & 7.6 & .38 & .43 & 0.05 & .29 \\
\hline 2 & $1.2 \mathrm{l} / \mathrm{min} 25 \mathrm{RPM}$ & 1 & 7.02 & 7.6 & .29 & .39 & 0.1 & .24 \\
\hline 3 & $1.7 \mathrm{l} / \mathrm{min} 25 \mathrm{RPM}$ & 2 & 7.01 & 7.7 & .29 & .39 & 0.08 & .21 \\
\hline 4 & $0.7 \mathrm{l} / \mathrm{min} 50 \mathrm{RPM}$ & 1 & 6.8 & 7.8 & .37 & .39 & 0.15 & .24 \\
\hline 5 & $1.2 \mathrm{l} / \mathrm{min} 50 \mathrm{RPM}$ & 1 & 6.3 & 7.9 & .32 & .35 & 0.21 & .27 \\
\hline 6 & 1.71/min50RPM & 0.6 & 6.5 & 8.1 & .3 & .22 & 0.19 & .18 \\
\hline
\end{tabular}

\section{REFERENCES}

Ahmed.M.A.M.,Awadm.A.A,Afify.M.T.,Osman H.E 2013 "A new network design for forcing air to produce compost" Misr J. Agric Eng., 27 (2): 718-736.

Hong,J.H.;Matsuda,J.and Y Ikeuchi,.(1983)"High rapid composting of dairy cattle manure with crop and forest residues"" Transaction of the ASAE 26(3):533-451\&454

Hong,J.H.;Kenner,H.M.and el Well,D.L.(1998a) "The effect of continuous and intermittent aerationon composting hog manure amended with sawdust -progress report". An asae meeting presentation .paper no.984098. 


\section{الملخص العربي}

العوامل الهندسية المؤثرة على إنتاج السماد العضوي

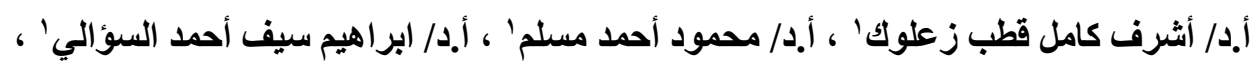

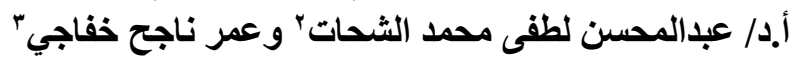

أجرى هذا البحث على التخمر الهوائى لخليط من مخلفات عضوية مختلفة : بعض فضلات الطيوروفضلات أطعمة وقشور خضروات وفو اكه وبعض المخلفات الزراعية وذللك بهدف

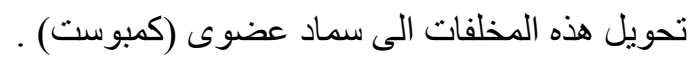
و هذه المخلفات تصل الى مصنع تدوير المخلفات الصلبة والزر اعية بأبو جريدة و التجربة تمت

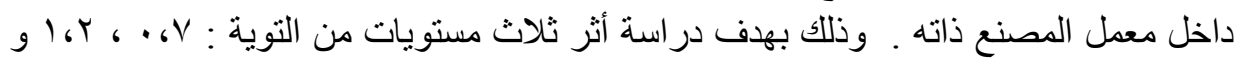

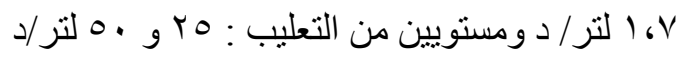
لإنجاز هذا الهدف تم تصميم وتتفيذ نظام للتخمر الهو ائى يتكون هذا النظام من كمبوستر هن هن

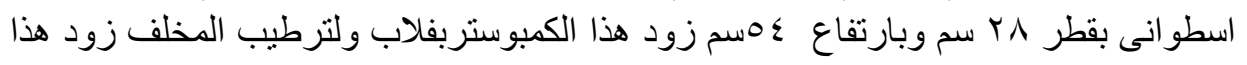

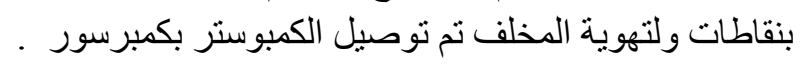

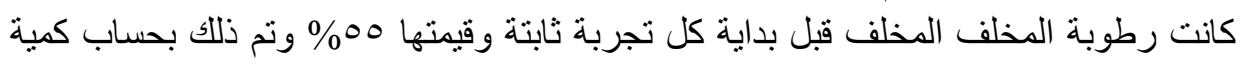
المياه التي تضاف للمخلف لتصبح رطوبته 00\% وتهوية المخلف المعامل بالكموستر كانت

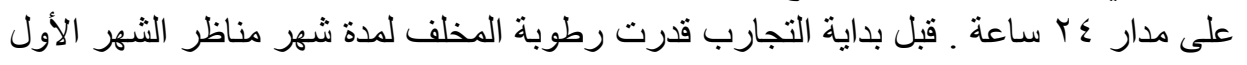

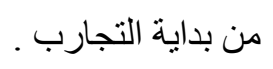
تم تقييم جودة الكمبوست الناتج بقياس وتقدير :

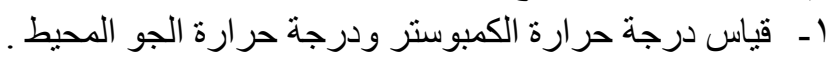

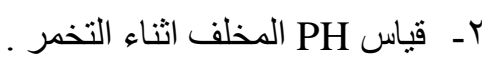

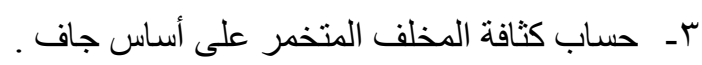

ثلاث مستويات تهوية ومستويات تقليب يعطيان ستة معاملات (تجارب) كل تجربة كانت ثثلاث

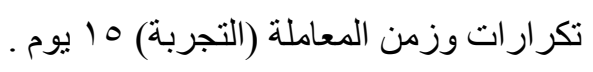

انتهت الدراسة الى أن أفضل معدل تهوية هو V، ، لتر/د و أفضل معدل تقليب هو هب لفة/د عند

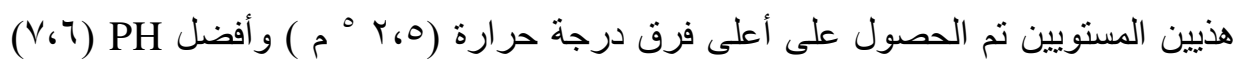

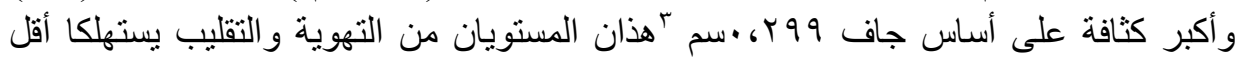

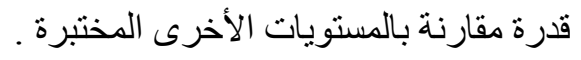

1. أستاذ الهندسة الزراعية ـ كلية الهندسة الزراعية - جامعة الأزهر.

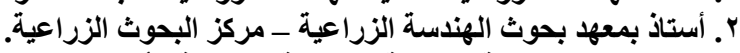
r. طالب ماجستير بكلية الهندسة الزراعية - جامعة الأزهر. 